\title{
PREDICATE FRONTING AND DATIVE CASE IN HUNGARIAN*
}

\author{
BARBARA ÜRÖGDI \\ Research Institute for Linguistics \\ Hungarian Academy of Sciences \\ Benczúr utca 33. \\ H-1068 Budapest \\ Hungary \\ urogdi@nytud.hu
}

\begin{abstract}
In this paper I provide a unified analysis of predicate clefts and a large class of secondary predicates in Hungarian. These constructions involve the occurrence of a predicate that is not immediately dominated by tense, which results in a striking similarity: in both, a verbal predicate takes the form of an infinitive, while nominal/adjectival predicates appear as dative. I argue that both the infinitive and the dative surface form indicate that the predicate's head is spelled out in a functional projection (commonly referred to as PredP or AspP) just outside the predicate's lexical projection, which is evidenced, among other facts, by phrase-internal modification patterns. Therefore, the structure of predication, including the position of modifiers, is claimed to be uniform, regardless of the lexical category of the predicate itself $(\mathrm{V}$, A or N). This result is strongly in line with research that views datives as predicates in general, and structural case on nominals as a reflex of a functional projection in the tense-aspect domain.
\end{abstract}

Keywords: dative, infinitive, predicate cleft, predication, secondary predication

\section{Introduction}

In this paper I provide a unified analysis of the predicate cleft construction and secondary predication in Hungarian. I argue that these two constructions have a crucial property in common - namely, the occur-

* I am grateful first and foremost to Katalin É. Kiss and Marcel den Dikken for invaluable discussions on this topic. 
rence of a predicate that is not dominated by its own tense projectionthat explains some interesting similarities between them. Although this structural analogy is evident in many languages when it comes to verbal predicates (which are usually infinitival in predicate clefts as well as in secondary predication), I will concentrate here also on nominal and adjectival predicates because in Hungarian these demonstrate a similar parallelism: the predicate occurs with dative case in both predicate clefts and in secondary predication. Based on the shared properties of secondary predication and predicate fronting on one hand, and the common distribution of infinitives and datives on the other hand, I argue for the following:

1. The structure of the predicative phrase, including the position of modifiers, is uniform, regardless of the lexical category of the predicate $\mathrm{X}$ itself (V, A or N).

2. At least in Hungarian, datives and infinitives are both the realization of an X head spelled out in the head of a functional projection dominating the lexical projection XP.

3. Therefore, the programmatic claim that datives are predicates receives strong support from the facts and analysis discussed here.

Unlike verbal predicate clefts, adjectival/nominal predicate fronting has not received much attention in the literature (although see Burányi 2003). ${ }^{1}$ An illustrative example is given below:

(1) Gazdag-nak' (János) gazdag volt (de mégsem volt boldog).

rich-dat (John) rich was (but yet-not was happy)

'Rich he (John) was, but he still wasn't happy.'

There are two characteristics of this construction that warrant a closer look. Firstly, it exhibits a well-known property of predicate clefts, namely a mismatch between the fronted predicate and the base predicate - the first being dative, while the latter bears no case. This mismatch manifests itself in verbal predicate cleft constructions as in (2):

(2) Beszél-ni' beszél-tem (de nem figyelt senki).

speak-inf speak-past.1sg (but not listened nobody)

'Speak I did, but nobody was listening.'

${ }^{1}$ In what follows, I use ${ }^{\prime}$ to indicate the typical rising intonation of contrastive topic, to differentiate it from focus, which I indicate with small capital letters. 
This evident mismatch is an issue that has mostly been glossed over by the authors on verbal predicate clefts for an obvious reason: intuitively, the topicalized form of the verb, that is, the infinitive, is somehow a "neutral", "unmarked" or "default" form. (Although note that this unmarkedness is only semantic and possibly syntactic - morphologically the infinitive is often not the bare form, as the Hungarian example above shows.) However, it would be difficult to claim that the dative form of an adjective or noun is less marked than the nominative or caseless form. In fact, at first glance, the exact opposite seems to hold.

A second, related issue is the mere fact that a predicate occurs with case. This is not a normal state of affairs, although we know of constructions - from Hungarian as well as other languages - where secondary predicates are case-marked. Incidentally, a large class of secondary predicates in Hungarian also surface as a dative ${ }^{2}$ if non-verbal, and as an infinitive if verbal:

(3) (a) János boldog-nak látszik.

John happy-dat seems

'John seems happy.'

(b) János örül-ni látszik.

John be-happy-inf seems

'John seems to be happy.'

Therefore the main line of my analysis will be the following: It is not an accident that secondary predicates and fronted predicates look the same, ${ }^{3}$

${ }^{2}$ Not all secondary predicates take dative in Hungarian, for example:

(i) János piros-ra festette a kerítést.

John red-onto painted the fence

'John painted the fence red.'

(ii) A kerítés piros-an tetszik nekem.

the fence red-on appeals to-me

'I like the fence red.'

And so on. These (and a handful of other) suffixes can also mark secondary predicates, and also alternate with a caseless form ( $A$ kerítés piros 'The fence is red'). Many but not all of these suffixes are related to locative case-endings, so it is plausible that they - like the dative - are spell-outs of a functional head selected by the matrix verb. This is something to be looked at in further research.

3 This also ties in with an observation in Landau (2004), who credits various authors for it: namely, that whatever constituent takes part in predicate fronting should be independently derivable in the language. While the relevant phrase observes 
since they share the property of not being "primary", that is, not being dominated by Tense. (For the basics of the idea that category and other formal properties are determined in syntax based on configurations of lexical and functional heads, see Pesetsky (1995) and others on Distributed Morphology.) I will claim that all of the examples (1)-(3) involve movement of the same phrase, and that the only difference between the doubling and non-doubling (i.e., "secondary predication") cases lies in the rest of the structure: whether or not the same predicate also happens to be the main predicate in the clause.

The paper is organized as follows. In section 1, I discuss the relevant examples from Hungarian in detail, and show that the construction in (1)-(2) is basically a standard instance of predicate fronting, similar to but less restricted than that found in Russian, Hebrew, Yiddish and a host of other languages. In section 2, I demonstrate the status of dative case in Hungarian and show that its distribution is in fact very similar to that of the infinitive. I will argue that this parallelism between the dative and the infinitive is well founded syntactically and makes sense semantically as well. Section $\mathbf{3}$ deals with a question that is relevant to all predicate cleft constructions: whether it can be shown that these constructions involve movement. In section 4 , I demonstrate that predicate (incl. secondary predicate) fronting involves phrasal movement, in particular, the movement of the functional projection dominating AP/NP/VP. Section 5 presents a brief overview of possible alternative analyses of this construction and counterarguments to these. Section 6 contains the summary, as well as an outline of the possible extensions of my conclusions.

\section{Data - a detour into Hungarian syntax}

In this section I will discuss the relevant observations about predicate fronting in Hungarian. It will be shown that, unlike in many other languages discussed in the literature, there is no uniform position targeted by the movement, no restriction on the surface position of the base copy, and no semantic requirements about the nature of the predicate. Although there exist certain syntactic constraints on the internal structure of the fronted phrase, these are related to general rules of Hungarian syn-

different restrictions in Hungarian from the ones noted for English and Hebrew (etc.), the intuition that these phrases should not be attributed properties not attested elsewhere in the grammar holds here as well.

Acta Linguistica Hungarica 53, 2006 
tax and are not unique to this construction. Therefore, the construction can be treated as a simple instance of predicate fronting, without any "special" properties.

As discussed in semantic literature on predicate clefts (among others: McCoy 2002), these constructions usually involve a special interpretation, which is commonly associated with contrastive topics. Observe this in the case of a simple example:

(4) [Tanár-nak'] tanár vagyok (de nem valami jó).

teacher-dat teacher I-am (but not very good)

'It is true that I'm a teacher but I'm not very good at it.'

Possible scenario: First speaker assumes that second speaker is good with children since he is a teacher. Second speaker concedes the condition (he is in fact a teacher) but contests the entailment (that he should be good with children) on the grounds of a piece of information not known to the first speaker (namely, that he is not good at his job).

It has been claimed or tacitly assumed for some languages that the semantic contrast in the above example is entailed by the predicate cleft construction: The speaker concedes a certain point, but at the same time states that that point is either not relevant, or does not lead to the consequence assumed by the listener/previous speaker. This is true for the typical case in Hungarian (4) as well but not a necessary condition on predicate fronting:

(5) Csak (elég) GAzDAG-NAK nem elég gazdag (amúgy tökéletes). only (enough) rich-dat not enough rich (otherwise perfect)

'It's only that he is not rich enough, otherwise he is perfect.'

Example (5) involves focusing of the predicate (marked by csak 'only') the fronted predicate (in small capitals) occupies focus position, is not a contrastive topic, and accordingly receives focus (and not contrastive topic) interpretation (to be clarified below).

Thanks to the articulated information structure of Hungarian (see e.g., É. Kiss 2002 and her earlier work), topic and focus are distinguished by word order as well as intonation: 


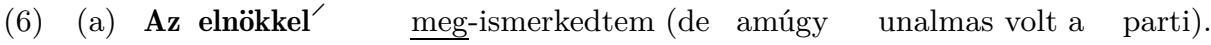
the president-instr perf-I-met (but otherwise boring was the party) 'The President I met, but otherwise the party was boring.'

Assumption: The speaker's goal at the party was to meet the president; therefore, he must have enjoyed himself if he succeeded in his goal.

Assertion: Speaker concedes that he met the president, but contests the entailment-claims that meeting the president did not make the party pleasant.

(b) AZ ELNÖKKEL ismerkedtem meg (nem pedig a helyettesével). the president-instr I-met perf (not conj the deputy-instr) 'It is the president I met, not the vice president.'

Assumption: The speaker met someone (and it was the vice president).

Assertion: It was the president and not anyone else that the speaker met.

As shown by the word order (observe the position of the perfective particle $m e g$ in the two examples above) and the intonation (rising on az elnökkel in (6a) but rising-falling in (6b)), the phrase with the president is in (contrastive) topic position ${ }^{4}$ in (6a) but in focus position in (6b). This is reflected in the interpretation. Similarly, the interpretations of (4)-(5) derive from the different target positions of the fronted predicate phrase, and not from the fact of the fronting itself.

Just as the position targeted by predicate fronting is not uniform, the surface position of the base copy of the predicate is also not restrictedalthough it is often focused, this is not obligatory, shown by example (7) below, where another element (the subject) is in focus:

(7) [Gazdag-nak'] PÉTER gazdag (de nekem mégis János tetszik jobban).

rich-dat Peter rich (but I still like John better)

'It's Peter who is rich, but I still like John better.'

Assumption: Speaker likes rich men and would therefore like Peter, not John.

Assertion: Speaker concedes that Peter is the rich one but states that the entailment in the assumption does not hold true.

So the generalization that seems to hold about Hungarian predicate clefts is that the surface positions of the fronted predicate or of the predicate

${ }^{4}$ Whether the contrastive topic position is a syntactically unique position or one of the iterative topic projections is a question that I leave open here. While it is true that contrastive topics receive special intonation and semantics, and there can only be one such topic per sentence, they can be preceded and followed by regular topics without restriction. This is not relevant to anything I have to say here. 
left behind inside the clause are irrelevant for the availability of fronting and the assignment of dative case. ${ }^{5}$ Whenever the predicate is fronted, the doubling and the dative case become available. Therefore - given the fact that there are also no semantic restrictions as to which predicates can be doubled - in what follows I will treat these examples as general cases of predicate fronting, with the added complication of double pronunciation, regarding which I refer the reader to the extensive literature on the topic. ${ }^{6}$

Now let us examine the properties of the fronted predicate phrase. The main constraints on nominal and adjectival predicate fronting are summarized below:

(8) Post-head modifiers are not present in the fronted phrase: ${ }^{7}$

[Büszké-nek (*Péterre)] büszke volt (Péterre),

proud-dat Peter-loc proud was (Peter-loc)

de sajnálta, hogy kevesen látták a győzelmét.

but he-was-sorry that few saw the victory-acc

'As for being proud of Peter, he was, but he was also sorry that so few people had seen his victory.'

(9) The copula is not present in the fronted phrase:

[Büszké-nek (*volt/*lenni)] büszke volt.

proud-dat was/ to be proud was

'As for being proud, he was.'

Notice that this latter fact points to an analysis of the copula that I will assume here without defending it: that the Hungarian copula is not a verb, but rather the spell-out of some functional projection outside the

${ }^{5}$ To position this phenomenon among predicate fronting constructions crosslinguistically: As evidenced by the languages examined in the literature (see references at the end of this paper), predicate fronting constructions fall into two classes. In the first class (seen in various Creole languages, among others) the fronted predicate receives a particular interpretation (i.e., contrastive topic) and there are strong semantic and syntactic restrictions applying to the fronting. In other languages (such as Hebrew or Hungarian) the fronting is much freer, and the syntactic process much more easily viewed as a regular instance of constituent fronting.

${ }^{6}$ For a comprehensive overview of multiple spell-out options in predicate fronting cross-linguistically, as well as strong arguments for the compatibility of multiple pronunciation and movement, see Landau (2006) and references therein.

${ }^{7}$ Whether post-head modifiers are not there in the fronted phrase or they are deleted is a question I return to later on. 
predicate phrase that is fronted here (probably T). ${ }^{8}$ This is not a general restriction on $\mathrm{BE}$ since it can occur in a fronted predicate when it is inserted under a verbal node - shown by the fact that it is modified by an adverb:

(10) [Otthon len-ni] otthon volt (de nem nyitott ajtót).

home be-inf home was (but not opened door-acc)

'As for being at home, she was, but she wouldn't open the door.'

Without further discussion I will just treat examples like (10) as simple verbal examples, where the pre-verbal modifier (often labeled "verbmodifier" in grammars of Hungarian) fronts along with the verb. This is a general constraint on predicate fronting examples involving a verbal predicate, as shown below:

(11) (a) [Haza men-ni] haza ment (de nem tudott aludni).

home go-inf home went (but not could sleep)

'He did go home but he couldn't fall asleep.'

(b) [Jól ír-ni] jól ír (de nincs benne önfegyelem). well write-inf well he-writes (but there-isn't in-him discipline)

'He does write well, but he doesn't have any discipline.'

(c) [Kez-et ad-ni] kez-et adott (de rögtön továbbállt). hand-acc give-inf hand-acc he-gave (but immediately went-on)

'He did shake hands with me, but then he immediately went away.'

(d) ? ?Péter-t választa-ni] Péter-t választottam

Peter-acc choose-inf Peter-acc I-chose

(de már nem tudom, miért).

(but anymore not I-know why).

'As for choosing Peter, I did, but I no longer know why.'

As the above examples show, basically any complement can front with the verb, as long as it is left-adjacent to the verb in the surface form of the base sentence - in the terms of standard Hungarian syntax it is "in the verb-modifier position". Nominal/adjectival predicates are subject

${ }^{8}$ Similar restrictions on the fronting of the copula have been observed for Hebrew (Landau 2004) and Russian (Abels 2001). While my analysis (outlined in what follows) provides a straightforward explanation for the restriction as it applies to Hungarian, it is unclear at this point how and whether it can be extended to cover the Hebrew and Russian facts. I will offer some tentative comments on this matter later on. 
to the same restriction when fronted: modifiers of the adjective can front along with the predicate as long as their neutral position is pre-head, as illustrated below - imagine the following sentences in the context of a casting agent describing potential candidates for certain parts:

(12) (a) Átlagos testalkatúnak átlagos testalkatú volt... average built-dat average built was 'As for having an average build, he did (but the costume still didn't fit him).'

(b) Közepesen magasnak közepesen magas volt... medium tall-dat medium tall was 'As for being medium height, he was (but he wasn't what we were looking for).'

(c) *Péter-nél magasabb-nak Péter-nél magasabb volt... Peter-adess taller-dat Peter-adess taller was

'As for being taller than Peter, he was (but otherwise he didn't fit the description).'

I will return to this point in section 4. For the time being, it should be noted that it is an independent fact of Hungarian syntax that a designated, usually predicative element (be it a particle, an adverb, a secondary predicate or an argument) occupies the preverbal position in a neutral sentence. ${ }^{9}$ This element is commonly referred to in the literature as the "verb-modifier" (or VM) because it displays a close connection with the verb by modifying its meaning, is often idiomatic (as in (11c) above), and has a fixed syntactic position. A similar restriction ${ }^{10}$ governs the neutral position of a modifier to an adjectival or nominal predicatesome modifiers (which, loosely speaking, describe a subtype in the case of a type predicate) are only natural in a pre-head position. While this is not by far a straightforward issue syntactically or semantically, it is marginal to what I have to say here. The only relevant point here is that the

9 The status of this element is a much debated area of Hungarian syntax. For one, its presence has aspectual relevance. Also, it is difficult if not impossible to distinguish it from focus, leading many researchers - among them myselfto believe that the "VM" position is indistinct from the position occupied by focus. Since this debate is largely internal to Hungarian grammar and would only confuse the non-Hungarian reader, I will attempt to stay as neutral on this matter as my subject allows.

${ }^{10}$ For some reason, the relationship between an adjectival predicate and its modifier has not received as much attention in the literature as the "verb-modifier" has. Nevertheless, I will treat the two types of modification analogously, which will be supported by the facts of predicate fronting.

Acta Linguistica Hungarica 53, 2006 
similar modification of different categories of predicates supports the idea that there is no crucial difference between them at the level of predicative structure. ${ }^{11}$ Therefore, I will not dwell too much on why this element occurs before the head, and will simply note that whatever element occurs immediately left of and in the same intonational phrase as the predicative head in the base sentence can and must front along with its predicate. In what follows, I will refer to such modifiers as predicate-modifiers or PM for short. For now, I will use this term as descriptive shorthand, although I will offer some thoughts on the nature and syntactic status of PM later in this paper. To allow for simplicity of presentation, I will simply label the functional projection outside the lexical predicative phrase "FP" (as opposed to the more meaningful "PredP" or "AspP" that are used in the literature) - by doing so, I wish to avoid taking a stand on the exact nature of this projection, simply noting that it houses the main assertion in the Hungarian clause. Thus, I will assume that the prehead position of the PM arises via head movement of the lexical predicate to the head of FP and raising the PM from a lower predicative position into $[\mathrm{SpecFP}]$, as in (13):

(13) $\left[\mathrm{FP}\right.$ hazai $\left[\mathrm{F}^{\prime}\right.$ ment $\left.\left._{j}\left[\mathrm{vP}_{\mathrm{j}} \ldots \mathrm{t}_{\mathrm{i}}\right]\right]\right]$

I take FP thus to be the locus basically of complex predicate formation wherein lower predicates become the modifiers of higher predicates, while at the same time retaining their dominant position by landing on the left edge, and thus receiving main sentence stress. Whether the "low predicative position" is that of a low argument in a Larsonian model, or the predicate of a small clause is not important for the purposes of the present topic. Although I am more sympathetic to the latter approach, discussing it would take me too far off course.

Note that the positional requirement of the PM is so strong that it will be pre-head in the fronted phrase even if this does not mirror the state of affairs inside the base sentence:

(14) [El-lop-ni] PÉTER lopta el a könyvet, away-steal-inf Peter stole away the book-acc

(de a húga hozta vissza).

(but the sister-his brought back)

'As for stealing the book, that was Peter's doing, but it was his sister who returned it.'

${ }^{11}$ Contra, among others, famous work by Bowers on predication, who claims that only verbal heads move out of their lexical projection to $\operatorname{Pr}($ ed). For the latest version of Bowers' predication theory, see Bowers (2001).

Acta Linguistica Hungarica 53, 2006 
In (14), the particle $e l$ is in the preverbal position in the fronted phrase, but inside the base sentence it has separated (for independent reasons) from the verb, since the verb must be right-adjacent to the focused element-i.e., there is a functional projection housing the focused subject in its Spec and the verb in its head. ${ }^{12}$ Although the internal structure of the base sentence presents a theoretical puzzle in itself, it is at least clear that the surface order in the fronted phrase does not mirror the surface order in the base - ruling out an approach involving PF-echo effects. This is shown also by cases of long-distance fronting, as in (15):

(15) El-lop-ni el akartam [t] (de nem sikerült).

away-steal-inf away I-wanted (but not worked)

'As for stealing it, I wanted to do that but it didn't work out.'

Although this is a complicated example and I will provide a detailed analysis of it in section 4, it is easy to note again that the PM occurs before "its own" predicate in the fronted phrase (el-lopni) although such a combination is not found in the rest of the sentence (because, again for independent reasons, el has raised up to become the PM of the matrix predicate akartam in a form of clause union; on the details of this see É. Kiss 2002).

So, based on the above, the generalization is that the predicate plus its PM are what can (and must) be included in the fronted phrase. As a related fact, subjects can never front:

(16) (a) *[Én utál-ni] én utálom Pétert (de miért fontos ez?)

I hate-inf I hate Peter-acc (but why important this)

Intended meaning: 'It's true that I'm the one who hates Peter...'

(b) ??[Vendég érkez-ni] vendég érkezett (de már el is ment). guest arrive-inf guest arrived (but already away part went) Intended meaning: 'It's true that a guest arrived but he's already left., ${ }^{13}$

${ }^{12}$ Whether this functional projection is a special "FocusP" or not is again an open question. In what follows, I will label it as such for ease of exposition, noting that there are a good number of other theoretical possibilities (i.e., that "FP" housing the PM is iterative, or that sentences containing a Focus are biclausal, with Focus predicated of the entire sentence, and so on).

13 The latter example is strange because the surface subject is actually a deep theme, which does end up in the preverbal position in a neutral sentence due to a restriction on non-specific bare nominal arguments (i.e., *Érkezett vendég is ungrammatical) - therefore its inability to occur in the fronted position is unex- 
A set of interesting examples involves an added layer of predication on an argument of the verb, usually the direct object, although other arguments are also possible:

(17) (a) Vers-nek vers-et írt (de szabadverset).

poem-dat poem-acc she-wrote (but free-verse-acc)

'It's true that it was a poem that she wrote but it was free verse.'

(b) Vers-nek vers volt, amit írt...

poem-dat poem was what wrote..

The interpretation of such sentences is similar to that of (4), so they would both be natural in the following situation: The kids in a class are supposed to write poems for Christmas. The teacher of the class is complaining to a colleague about a certain student who never does what she is supposed to. The colleague asks: "So, again she did something other than the task? Did she not write a poem but something else-a joke, a cartoon caption, a short story?" The teacher responds: "It was a poem that she wrote, that's not the problem - the problem is that she wrote free-verse." While (17b) obviously fits in with the other facts I deal with here since it involves a predicate (poem) fronted and receiving dative, (17a) is seemingly an exceptional case. It should be noted, however, that all of my examples involve "predicate fronting" of elements that start from a predicative position in the derivation - and it has been argued that all PM's share this property. In particular, Komlósy (1992) claims that a complex predicate such as verset ir 'poem-writes' starts from a deep structure like "he writes [something, and that something is a] poem", which would technically make the PM in (17a) a null-headed relative that is predicated of an empty direct object. (See den Dikken forthcoming for a parallel analysis of English predicate inversion.) Although the scope of this paper does not allow for the detailed elaboration of this idea, I

pected. But (16b) is not exactly as bad as (16a), which might mean that (16b) is not ungrammatical but pragmatically or semantically odd. Since subjects in the preverbal position have a tendency to be interpreted as focus in Hungarian (given that the preverbal focus is basically indistinguishable from - and possibly syntactically in the same position as - the PM; see footnote 9) the oddness might be due to trying to interpret the same element "guest" as focus and topic simultaneously. This is, of course, impossible (see for example den Dikken forthcoming for discussion). (See also the slightly marginal status of (11d).) The point is that in (16b) the interpretation must be construed so that vendég érkezett 'guest arrived' is a complex predicate, otherwise "guest" must be interpreted as focus, and the sentence becomes incoherent. 
believe that it can be convincingly shown that examples (17a) and (17b) are more analogous than the surface shows, and thus my analysis can be extended to both. ${ }^{14}$

\section{Interim conclusion 1:}

The properties displayed by the fronted phrase are unrelated to the surface position occupied by the phrase (topic or focus). Therefore I hope to show in what follows that all properties (content and morphology) of the fronted phrase can be derived from its internal structure and its starting position (i.e., that it must be predicative). Whenever and wherever such a fronted phrase is spelled out, it will have the same properties (dative case on adjectival/nominal predicates, and verbal predicates appearing in the infinitival form, each accompanied by its normal predicate modifier).

14 There is another class of examples that I will not go into in detail here. This type has been discussed in the literature on Yiddish (Cable 2004; Landau 2004; Davis -Prince 1986) predicate clefts among others under the term pseudo-infinitives. These are infinitival forms that are "regularized" in the sense that they involve the mechanical adding of the infinitival suffix ( $-n i$ in Hungarian) to the root, without regard to irregular infinitival forms. Observe the Yiddish and the Hungarian examples below:

(i) Veysn / *visn veyst zi es. (Yiddish; from Cable 2004) know-inf knows she it 'She KNOws it.'

(ii) Van-ni / *lenni van pénzem (de nem elég). is-inf / be-inf is money-mine (but not enough) 'It's true that I have some money but not enough.'

(iii) ? Van-ni nincs (de megpróbálok szerezni). is-inf not-is (but I-try get-inf)

'We don't actually have any but I will try to get some.'

(iv) ? Vol-ni vol-t (de elfogyott). was-inf was-past (but ran-out) 'It's true that there was some but it ran out.'

Although the last two examples are slightly marginal, the pseudo-infinitive of be occurs in (16b)-type sentences often-actually, the normal infinitive lenni of be is not possible in such existential constructions. This is an intriguing fact, pointing to an analysis of the be of existential sentences (which is most likely focused but in any case sentence-initial except for topics) that sets it apart structurally from the copula (which cannot occur in fronted predicates, and is probably a spell-out of $\mathrm{T}$ ) as well as from the be inserted under $\mathrm{V}$ (which occurs in fronted predicates in its "normal" irregular form). 


\section{Proposal about the nature of dative case in Hungarian}

Now let us return to the question of why and how fronted nominal and adjectival predicates end up with dative case. Since I hope to show that this emergence of dative is not exceptional at all, let me summarize the general occurrences of dative in Hungarian. It should be noted from the discussion below that (a) most datives in this language are predicative; (b) secondary predication in particular shows a similar distribution of infinitives and datives; and (c) it can therefore be claimed that when a predicate is "secondary" in the precise sense to be defined below, it surfaces as an infinitive if it is a verb, and as a dative if it is a noun or adjective.

(18) (a) Goals:

Péter-nek adtam az összes pénzem.

Peter-dat I-gave the all money-my

'I gave all my money to Peter.'

(b) Have-sentences:

Péter-nek rengeteg pénze van.

Peter-dat a-lot-of money-his is

'Peter has a whole lot of money.'

(c) Raised possessors: ${ }^{15}$ Péter-nek elveszett a pénze.

Peter-dat got-lost the money-his

'Peter's money has been lost.'

(d) Beneficiaries:

Péter-nek élek.

Peter-dat I-live

'I live for Peter.'

Although I will only concentrate on standard cases of secondary predication while making my argument, note that other occurrences of the dative in Hungarian also involve predication, at least on certain theories

${ }^{15}$ I am assuming (contra Tóth 2002; in the basic spirit of É. Kiss 2001) that dative "subjects" of inflected infinitives can be analyzed as possessors, and thus as predicates. An example of this construction is:

(i) Péter-nek men-ni-e kell.

Peter-dat go-inf-3sg must

'Peter has to go.'

For arguments for and against the possessor-analysis of these datives, see the above papers. In order to avoid overcomplicating this discussion, I do not take up this issue here. 
and assumptions. ${ }^{16}$ In particular, if we predict that dative case and an added layer of predication go hand in hand, this provides support for analyses of goals and possessors as predicates in their own right. Since this is not crucial to the point I wish to make here, I will use as illustration occurrences of the dative case that are unarguably predicates under any theoretical assumptions.

The most straightforward instances of dative predication are as follows:

(19) (a) Péter okos-nak / zseni-nek látszik.

Peter smart-dat / genius-dat seems

'Peter seems like a smart man/a genius.'

(b) Péter-t okos-nak / zseni-nek tartják.

Peter-acc smart-dat / genius-dat they-consider

'Peter is considered smart/a genius.'

(c) Péter politikus-nak készül.

Peter politician-dat prepares

'Peter is preparing (planning) to become a politician.'

(d) Péter-t elnök-nek választották.

Peter-acc president-dat they-elected

'Peter has been elected president.'

Examples (19a-d) show standard cases of secondary predication, meaning that the adjective or noun is obviously predicated of the DP (Péter $(t))$ that has become (depending on the selectional grid of the matrix verb) the main clause subject or object. The interesting fact about these Hungarian cases is that the secondary predicate itself occurs in dative case, and it occupies the preverbal position in the matrix clause. In effect, it has formed a complex predicate with the matrix verb, something like "seems to be a genius" or rather "genius-(to-be)-seems" — so its status is clear, at least from an interpretational point of view.

Now, the question still remains: where does the dative case come from? If we are to posit a local relationship between the subject and the secondary predicate in $(19 \mathrm{a}-\mathrm{d})$, for example, the most standard way to achieve this is through a small clause - without a verb, naturally, since

${ }^{16}$ In particular, see Marcel den Dikken's well-known work on the possessive construction, arguing that the possessor should be analyzed as a predicate, rather than a subject, in these phrases. See for example den Dikken (1999) for discussion. 
there is no copula in Hungarian where there is no tense to be spelled out. This makes it implausible, however, that the matrix verb should be the dative case-assigner: once the $\mathrm{SC}$ is formed, the subject must raise for case, but the predicate (which, by definition, does not need case) has no motivation for movement. And even if the motivation were simply structural (some form of clause-union or predicate-incorporation), this would not explain why case assignment is required. This makes natural the suggestion that dative case is assigned inside the small clause.

There is an alternation that, in my opinion, sheds light on this issue:

(20) (a) Péter boldog-nak látszik.

Peter happy-dat seems

'Peter seems happy.'

(b) Péter örül-ni látszik.

Peter be-happy-inf seems

'Peter seems to be happy.'

The examples in (20) are nearly synonymous, with the difference that the secondary predicate in (20a) is an adjective, and in (20b) it is a verb. Given that they both start out as predicates (of a small clause), it seems natural to assign them similar structures with a single difference: while (20a) has an adjectival predicate in the small clause, (20b) contains a verb. I suggest that, in both cases, the lexical predicate head-moves to $\mathrm{F}$ (the head of the functional projection dominating the lexical projection of a predicate), FP is later moved to the PM position of the matrix clause ([SpecFP] dominating the matrix VP), and the SC predicate is spelled out in this position - as dative in the adjectival case, and as infinitive in the verbal case. The derivation is shown below (without the subsequent movement of the SC subject to Spec,TP and later to Topic): ${ }^{17}$

${ }^{17}$ In the trees, I have added [+ fin] and [-fin] for ease of exposition; I am not implying that these two $\mathrm{F}$ heads are inherently different - but $\mathrm{F}[+\mathrm{fin}]$ is immediately dominated by T, while F[-fin] is not. Since "F" may very well be the locus of Aspect (among other things), it is plausible that it enters into some formal relationship with $\mathrm{T}$. 
(21) (a) Péter boldog-nak látszik.

Peter happy-dat seems

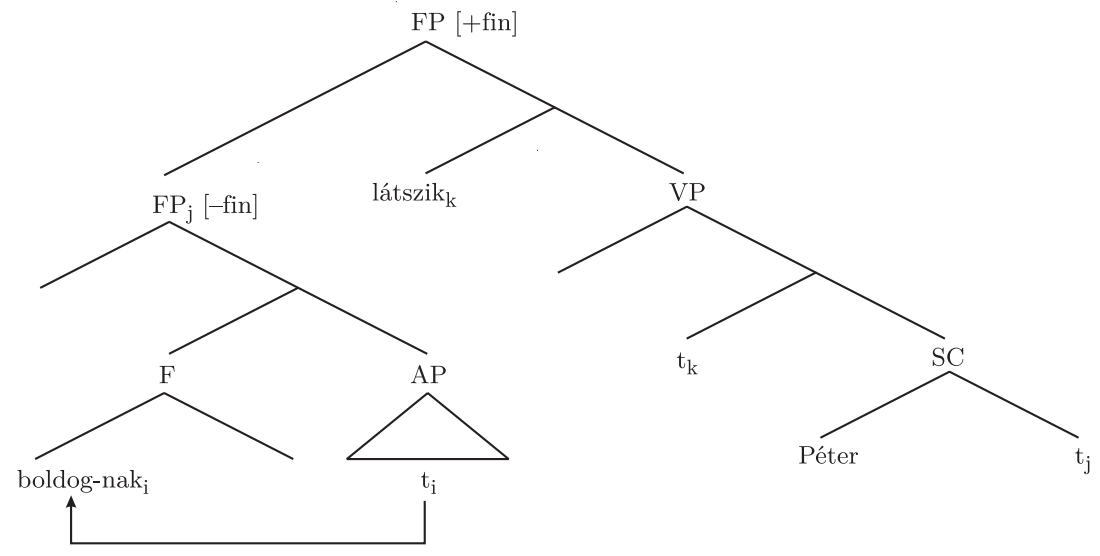

(b) Péter örül-ni látszik.

Peter be-happy-inf seems

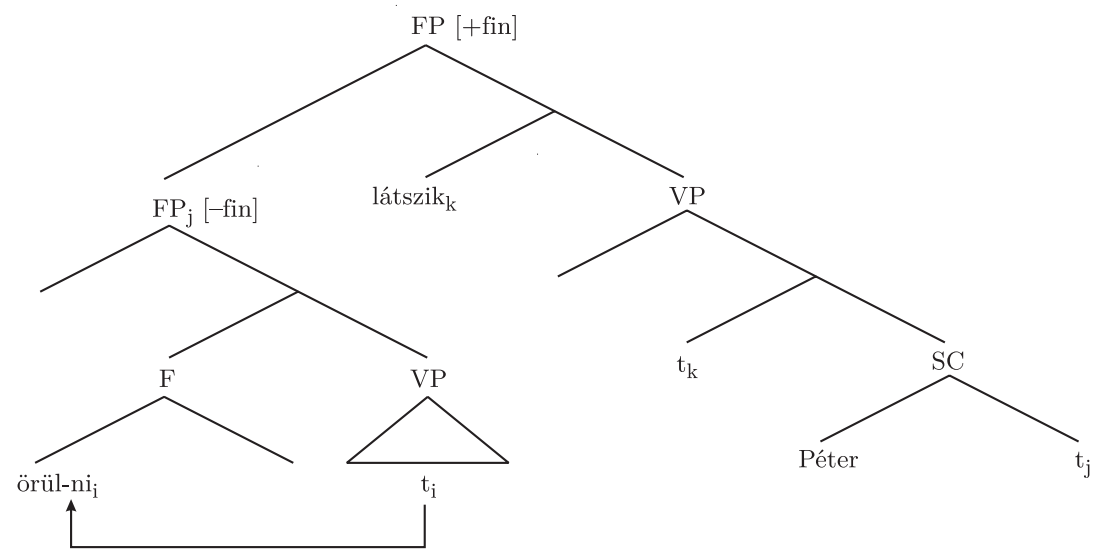

Note that the structures above contain an empty Spec position left of the fronted predicate, which is in fact recursive, that is, the embedded predicate can also attract its own PM into its Spec, just like the matrix predicate attracted it. The fact that at least some modifier (in particular, the already mentioned predicate-modifier) moves along with the predicate to the matrix clause in these constructions is shown by examples like (22) below, where the verb is modified by a particle or a bare adverb, and (23), where the nominal or adjectival predicate has a modifier: 
(22) (a) Péter meg-hatód-ni látszott.

Peter part-be-touched-inf seemed

'Peter seemed to be touched.'

(b) Péter haza-indul-ni készült.

Peter home-start-inf prepared

'Peter was preparing to leave for home.'

(23) (a) Péter-t rendkívïli zseni-nek tartják.

Peter-acc exceptional genius-dat they-consider

'Peter is considered to be an exceptional genius.'

(b) Péter átlagos testalkatú-nak tünik.

Peter average built-dat appears

'Peter appears to have an average build.'

In (22)-(23), it is clear that the chunk moving to the PM position of the matrix clause (in bold above) must contain a phrasal layer since it contains a modifier. The assumptions about verbal predication-namely, that right outside the core VP there is a functional phrase (PredP or AspP in the literature), whose head houses the $\mathrm{V}$ and Spec houses the verbmodifier, a designated modifier of $\mathrm{V}$ that most affects its meaning and aspectual properties - extend naturally to predicates of other categories, as will be shown in section 4 . The advantage of such uniform treatment is that no special provisions need be stated for secondary predication or small clauses in general: the predicate head ( $\mathrm{V}, \mathrm{A}$ or $\mathrm{N})$ raises to $\mathrm{F}$ - in this case, non-finite FP is the maximal predicative projection in the lower clause; in other words, there is a full predicate (including modification and aspect) but there is no tense. Subsequently, this lower FP raises to form a complex predicate with the matrix verb in cases where the higher structure requires such movement - that is, where it later turns out that the finite predicate is a different one. Thus the structure of the relevant portion of $(22 \mathrm{~b})$ becomes as below:

$\left(22^{\prime}\right) \quad\left[\mathrm{FP}\left[\mathrm{FP} \text { haza }\left[\mathrm{F}^{\prime} \text { indulni }\right]\right]_{\mathrm{i}}\left[\mathrm{F}\right.\right.$, készült $\left.\left.\mathrm{j}\left[\mathrm{VP} \ldots \mathrm{t}_{\mathrm{j}}\left[\mathrm{SC} \ldots \mathrm{t}_{\mathrm{i}}\right]\right]\right]\right]$

Interim conclusion 2: Dative case is structural - it occurs when a nominal or adjectival predicate is spelled out (for any reason) in the head of a non-finite FP (that is, FP not directly dominated by Tense). This configuration obtains for one whenever a lower FP raises to a higher position and therefore the nominal/adjectival predicate raises no further than this position. 
As I have implied above, a point pursued in this paper is that the occurrences of predicative dative case (or of the infinitival form of the verb) are structural in the sense of configurational. By this I mean the following: there are independent spell-out conditions dictating which copies in a movement chain are spelled out in any given structure. Normally, these conditions have the effect of forcing the spell-out of the highest copy of a lexical item, and this is so in all examples treated above. These conditions will, for example, take a structure like (21a) and state that the highest copy - sitting inside the raised FP - shall be pronounced. The form which this copy takes is dependent on morphology and various other lexical constraints - in this case, since the relevant copy is situated in the head of non-finite FP (=FP not directly dominated by T), it will be pronounced as dative, just as a verb in the same position in (21b) takes the form of the infinitive. Note that this is not a default form in any sense - no more is the infinitive a default verb than the dative is the default form of an adjective or noun. If anything, we expect secondary predicates to be more marked morphologically than their primary counterparts - and this is so. The point is (and this is strongly in accordance with Distributed Morphology) that the spell-out of a verbal head in F (i.e., a predicative position without tense) is the infinitive, just as an A or $\mathrm{N}$ spelled out in the head of FP (again, a predicative position without tense) is the dative. ${ }^{18}$ As I plan to show, this point is nicely supported by predicate fronting.

As pointed out by many authors (on predicate fronting by Landau 2004), so-called "exceptional" constructions are often anything but exceptional. What they are is windows into aspects of the process of structurebuilding that are otherwise masked by surface syntax. In the case of predicate fronting, this idea manifests itself particularly clearly. While the clause itself is built up in the usual way, the non-finite version of FP (formed the same way in small clauses and in matrix clauses, sincebarring look-ahead - these higher structural levels are not yet visible at this stage) also happens to be spelled out due to the requirements of Topic or Focus (i.e., the ban on null topics or foci). Through fronting,

\footnotetext{
${ }^{18}$ An issue for further research would be to see if such structural parallels between the dative and the infinitive can be extended naturally to other languages. One obvious candidate is English, where goals and infinitives are both introduced by the preposition to (which could easily be housed in F). Another place to look for such parallels might be languages like Japanese, where the verbal and adjectival predicates can appear with the same marking in certain configurations (e.g., predicate fronting; Tomoyuki Yabe, p.c.).
} 
FP is removed from under the dominance of $\mathrm{T}$ and, as such, receives the same pronunciation as non-finite FP in (21) for example. Thus, rather than involving any form of "exceptional case-marking", predicate fronting supports an important point: that secondary predication has no special properties. To be more precise, if we posit that the lowest layers of structure are built up uniformly, based on simple lexical properties and syntactic principles, we must draw the conclusion that whatever morphological differences appear on the surface are due to higher structures and their requirements.

To illustrate, let us look again at the examples in the introduction, which I have claimed involve the same FP-formation, and a basic, neutral sentence:

(24) (a) János boldog volt.

John happy was

'John was happy.'

(b) János boldog-nak látszik.

John happy-dat seems

'John seems happy.'

(c) Gazdag-nak' (János) gazdag volt (de mégsem volt boldog). rich-dat (John) rich was (but yet-not was happy) 'Rich he (John) was, but he still wasn't happy.'

(24a) involves a simple sentence, therefore the highest occurrence of the adjective will move to $\mathrm{T}$ to support the inflection (spelled out as the copula), as shown below:

(24) (a') János boldog volt. John happy was

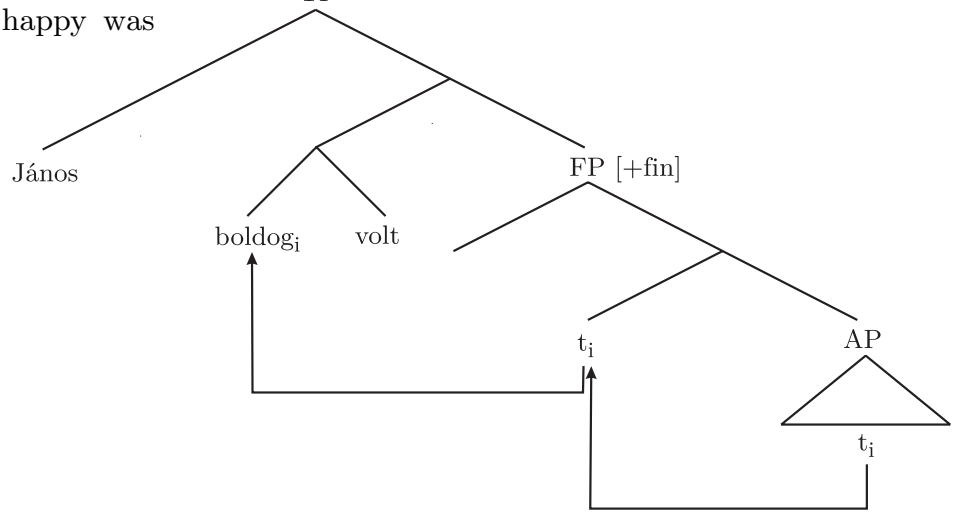


Let's now look at (24b). Unlike in (24a), here the head position of the lower, non-finite FP (which is not directly dominated by Tense) is the highest position reached by the adjectival predicate - since the finite predicate happens to be a different one, and therefore the adjective stays put in its first-derived position. Thus, the morphological configuration for dative spell-out obtains:

(24) (b') János boldog-nak látszik.

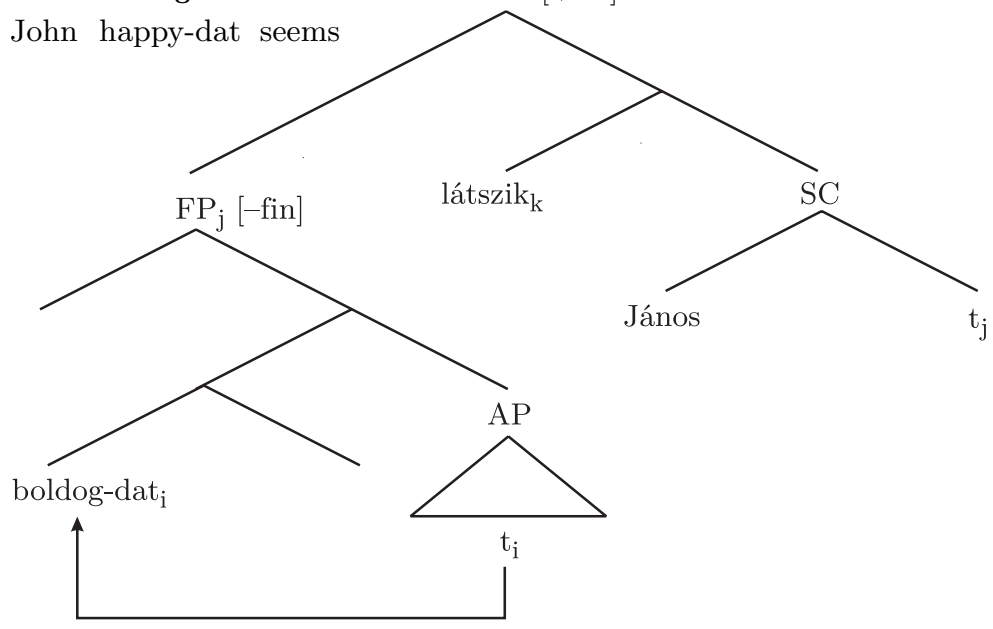

Finally, $\left(24 \mathrm{c}^{\prime}\right)$ displays what is predicted for the structure of predicate fronting. In a sense this structure is a combination of (24a) and (24b): while the adjective moves out of its own projection to become the main predicate, its copy in the head of FP is also spelled out due to the fact that no null topics are allowed - therefore, when the chunk moved into Topic happens to be an FP undominated by Tense, its content must be pronounced as non-finite - that is, as an infinitive if the predicative head is a verb, and as dative if the head is an A or N.

Notice that the mere fact that an adjective or noun is moved to contrastive topic does not result in dative case assignment, observe (25). 
(24) (c') Gazdag-nak' (János) gazdag volt... rich-dat (John) rich was

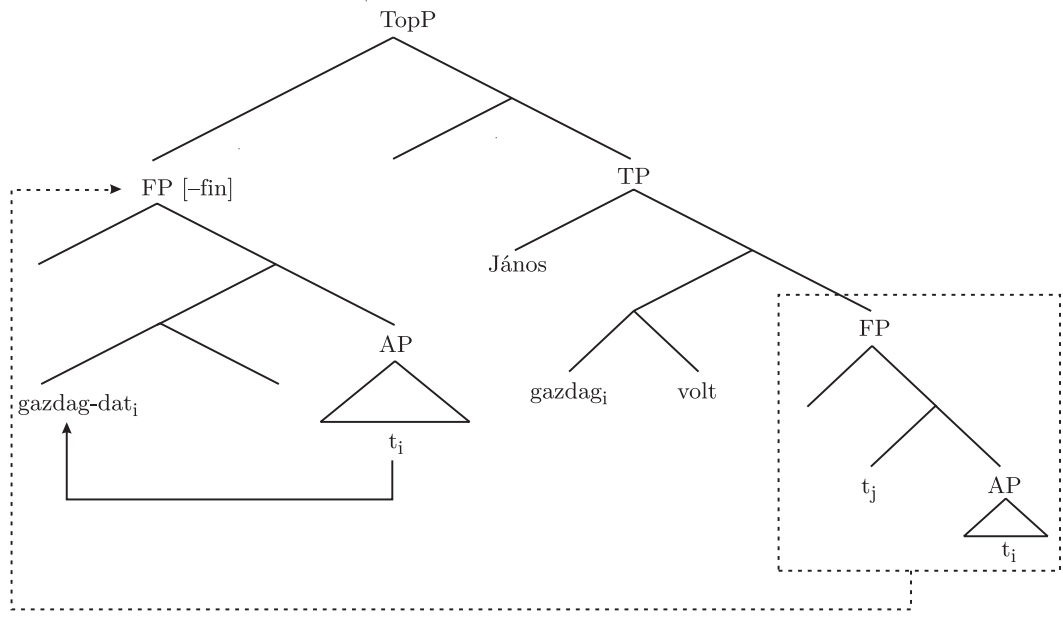

(25) (a) Boldog' volt János de gazdag nem. happy was John but rich not 'John HAs been happy (in his life) but not rich.'

(b) Boldog-nak' boldog volt János de mégis aggódtunk érte. happy-dat happy was John but still worried-we for-him 'Happy John was but we still worried about him.'

While (25a) involves movement of the AP into contrastive topic, ${ }^{19}$ (25b) is the now-familiar FP-fronting. The difference is apparent from the interpretation: while in (25a) it is merely the property of happiness that is contrasted with other properties, in (25b) the state of being happy is contrasted with other related facts (here: the fact that we still worried about him). At least according to some speakers, AP-fronting such as in (25a) is only possible on an in-his-life interpretation, where the copula is in focus - presumably this higher movement of the tense head frees up the predicate itself for topicalization. Or rather, the fact that the copula constitutes the main assertion in (25a) degrades the AP to the status of modifier. But the point here is that the presence of dative in (25b) signals

19 Consequently, this is a simple case of constituent topicalization, available in Hungarian for DP's most generally, but (as we see here) also for larger units. Whether any phrases larger than FP can be fronted is an open question. 
that something else is at work - according to this paper, the something else is the fronting of a larger chunk, namely FP.

Crucially, the fact that the adjective is pronounced with dative and verbs come out as infinitives in this position provides support for the claim that it is this same FP that is involved in secondary predication. It also shows that secondary predication is a derivational concept, that predicates move through the same configuration in small clauses as they do in finite sentences - if this were not so, we would have no plausible explanation for why predicate fronting examples like (24c) should involve "secondary predicates". The simple intuition is that predication exists with different layers - thematic, aspectual, temporal - and these layers may coincide (as in simple sentences) or not (as in "secondary predication") - and may be teased apart thanks to "exceptional" phenomena such as predicate fronting.

\section{Is there movement in predicate cleft constructions?}

One question that is dealt with in detail in papers about predicate clefts (and about topicalization in general) is whether these constructions involve movement at all. Therefore, before I get into the question of what the fronted constituent is, I will briefly address the question of whether non-movement analyses are plausible or worth pursuing.

While it is quite obvious that the secondary predication cases discussed in the previous sections involve movement, the situation is much less clear when it comes to predicate clefts. There are two immediately obvious facts clouding the picture: firstly, there are two copies of the same element spelled out, and secondly, there is the well-documented mismatch between the two copies. As I have shown above, the appearance of dative case (and the infinitive ending) in Hungarian predicate clefts is not at all unexpected, so this factor is not decisive between a movement and a non-movement analysis. Leaving aside the question of multiple spell-out (and assuming that multiple pronunciation in itself is not an argument against movement), let me now turn to the question of whether any direct evidence can be found for fronting.

The standard tests for movement are also the ones cited in the predicate cleft literature as evidence for fronting. ${ }^{20}$ The same island-effects can be reproduced for Hungarian:

\footnotetext{
${ }^{20}$ See the references at the end of this paper.
} 
(26) Factive island:

(a) Bátor-nak azt hiszem / tudom, hogy bátor volt. brave-dat that-acc I-believe I-know comp brave was 'As for brave, I believe/know he was. (But he still didn't become a good soldier.)'

(b) *Beteg-nek sajnálom, hogy beteg volt. sick-dat I-regret comp sick was 'I do regret that he was sick. (But I'm still not sorry he didn't come to the party.)'

(27) Wh-island:

(a) Beteg-nek meg-mondom neked, hogy mikor volt beteg utoljára. sick-dat I-tell you comp when was sick last 'As for being sick, I can tell you when he was last sick. (But how will that help you figure out if he has taken all his sick leave?)'

(b) ?? Beteg-nek meg-kérdeztem, hogy mikor volt beteg utoljára. sick-dat I-asked comp when was sick last 'As for being sick, I asked him when he was last sick. (But I forgot to ask whether he took sick leave that time.)'

Such tests standardly show that there is a movement relation between the base-copy and the fronted copy at some point in the derivation. However, as pointed out by Cable (2004) and Vicente (2005) on different grounds, they do not actually rule out the base-generation analysis. Since all of the examples are biclausal, technically an analysis is possible where the dative version of the predicate is generated on the left edge of the lower $\mathrm{CP}$, and is subsequently moved to the topic position of the matrix clause. In such a scenario we would also expect to observe the island effects exemplified above (and in fact this analysis is argued for in Cable 2004).

However, as pointed out by Vicente (2005) in a paper on Spanish predicate clefts, monoclausal tests can also be constructed to detect movement on a local level. In particular, he observes that there are two dialects of Spanish differentiated precisely by their behavior with respect to such tests. The test used by Vicente to prove his point is the well-known coordination island test, shown below for Hungarian:

(28) *Szép-nek szép és okos volt (de...) pretty-dat pretty and smart was (but...)

'As for being pretty, she was pretty and smart (but...)' 
The coordination test shows local movement, and divides the dialects of Spanish into two groups: Dialect A, which patterns with Hungarianwhere association of the topic with just one of the conjuncts is illicit, showing movement; and Dialect B, which should pattern (at least superficially) with Yiddish, on which Cable bases his analysis (although Cable does not discuss these tests) - where (28) is grammatical. As Vicente (ibid.) observes, the availability of sentences like (28) corresponds with whether or not so-called "genus-species" predicate clefts are possible. This odd class of predicate clefts is allowed in a subset of the languages or dialects that have predicate clefts at all (for example, in Yiddish), and look like the example given below:

(29) Essen fish est Max hekht.

eat-inf fish eats max pike

'As for eating fish, Max eats pike.'21

The obvious characteristic of these "genus-species" sentences is that the element in the topic position is a more general term for what appears as the predicate inside the clause. As Vicente argues (and as many authors have observed), it is difficult to analyze these cases as instances of movement. Rather than take their mere existence as counterevidence for movement, however, Vicente observes that the availability of "genus-species" predicate clefts correlates with the possibility of associating one conjunct of a coordinate structure with the topic. As expected, Dialect B above, which allows examples like (28), also has no problem with sentences like (29). It can be concluded, therefore, that there is a dividing line between two types of predicate clefting: one (as in Dialect A) involving movement of some sort, and one involving base-generation.

As predicted, Hungarian also does not allow "genus-species" sentences, just like Dialect A of Spanish, and as shown below:

(30) (a) *Hal-nak harcsa volt, amit fogott.

fish-dat catfish was what-acc he-caught

'As for fish, what he caught was a catfish.'

(b) *Szép-nek gyönyörü volt, nekem mégsem tetszett. pretty-dat beautiful was me still-not appealed

'As for being pretty, she was beautiful, but I still didn't like her.'

${ }^{21}$ The example is taken from Cable (2004).

Acta Linguistica Hungarica 53, 2006 
Therefore, without taking a stance on Dialect B-type predicate clefts, I will henceforth assume that Hungarian predicate clefts do in fact involve movement, and thus fall into the same class as Dialect A-type Spanish dialects and all other languages that do not allow "genus-species" topics.

\section{What moves?}

Thus far I have been using the label "FP" in a slightly vague manner, which I will attempt to make more explicit below. In particular, I will show what can and must move along with the predicate in predicate fronting, in what way these elements form a natural class, and how to go about ruling out the fronting of other complements and modifiers that do not appear in Topic. As before, I refer to the projection just outside $\mathrm{VP} / \mathrm{AP} / \mathrm{NP}$ as FP, although nothing hinges on this decision, and a shellbased approach would enable the same result. ${ }^{22}$

To begin, let me mention an issue that comes up often in the literature on predicate clefts - namely, whether the movement involved affects a phrase or a head. This question is a natural one to raise for languages where no modifiers can move along with the predicate (actually, most literature on these constructions only deals with verbs). In Hungarian, the situation is obviously not so simple, since at least particles and the so-called "predicate-modifiers" can (and, if they are present, must) front along with their predicate, making something like (31) ungrammatical:

(31) (a) *Men-ni haza-mentem (de már nem maradt időm pihenni). go-inf home-I-went (but already not remained time-mine rest-inf) 'I did go home, but I didn't have any time left to rest.'

(b) *Testalkatú-nak átlagos testalkatú. built-dat average built

'As for his build, he has an average build.'

However, when the predicate occurs most naturally without any modifier in a neutral sentence, it obviously also fronts without a modifier, so the question of head vs. phrasal movement may be relevant in these cases.

${ }^{22}$ That is, $\mathrm{vP}$ involving the movement of $\mathrm{V}$ to light $\mathrm{v}$ is pretty much the same thing, except perhaps for the locus of categorical information. However, FP is intended to be more general, as it allows us to treat all predicative constructions analogously. 
In fact, it is argued in Landau (2004) for Hebrew that "when stranding its arguments, the fronted category [in predicate clefts] is a bare $\mathrm{V}$ (rather than a remnant VP)." As Landau's Hebrew facts show, an internal argument of the verb may be fronted along with it or stranded, as shown below:

(32) (a) [liknot et ha-praxim], hi kanta buy-inf acc the-flowers she bought

'As for buying the flowers, she bought (them).'

(b) [liknot], hi kanta el ha-praxim buy-inf she bought acc the-flowers

'As for buying, she bought the flowers.'

Simplifying Landau's analysis somewhat, his idea is that while an example like (32a) arises through VP-fronting and subsequent deletion of the subject, (32b) comes about via fronting of the $\mathrm{V}$ head to topic (so no remnant movement or deletion is required).

Notice that the issue arises for Hungarian in a slightly different way. There are three varieties of the same example to consider, all with distinct syntactic and semantic properties:

(33) (a) [Virágot venni] virágot vett...

flower-acc buy-inf flower-acc bought

'As for buying flowers, that's what he did (but I don't know where he did that).'

(b) [Venni] vett virágot...

buy-inf bought flower-acc

'Buy he did some flowers (but not nearly enough for the decoration)'

(c) [Venni] VIRÁGOT vett...

buy-inf flower-acc bought

'What he bought was flowers (but what he sold was fruits).'

(d) *[Venni virágot] (virágot) vett (virágot)...

As is apparent from the final, ungrammatical example (and as shown extensively above), post-head modifiers are ungrammatical in the fronted phrase. At the same time, whether or not the pre-head modifier will front along with its predicate depends on what actually forms the basis of the contrast. In (33a), the contrast is between the situation or act of flowerbuying and other possible scenarios. For example, the previous speaker may have asked "Didn't he buy flowers (= go flower-buying) earlier?" 
where the reply contains agreement with the whole predicate "flowerbought". On the other hand, $(33 \mathrm{~b}-\mathrm{c})$ contain examples where the basis of the contrast is simply the verb ("buying"); in the first case, the previous utterance may have been something like "Are you telling me that he didn't buy any flowers?" while in the second case "Didn't he sell flowers? I mean, I know that he bought flowers..." The crucial point is that it would appear from the interpretation that examples (33b-c) may be analyzed as topicalizing only the verbal head.

However, the situation is not as clear as that. Firstly, it must be noted that the difference between examples (33a) and (33b-c) lies not only in the content of the fronted element, but also in the structure of the base sentence. While the direct object is clearly a verb-modifier in (33a) - apparent from its neutral position left-adjacent to the inflected verb-, this is not the case in $(33 \mathrm{~b}-\mathrm{c})$. In $(33 \mathrm{~b})$, the inflected verb is in focus - shown by intonation and by the stranding of its accusative argument; ${ }^{23}$ in (33c), the direct object is in focus. Without dwelling too much on the Hungarian-specific details of where exactly the base sentences of the examples in (33) differ structurally, it can be concluded that whenever the predicate-modifier position (here: SpecFP) is filled in the base sentence, the element filling that position must front along with the predicate. ${ }^{24}$ Thus, the fact that the predicate head appears to be alone in Topic in $(33 \mathrm{~b}-\mathrm{c})$ may well indicate that the relevant modifier position is simply empty or filled with a silent element. ${ }^{25}$ Therefore, I

23 This is the normal state of affairs in Hungarian, where "in-his-life" or "accomplishment" readings - loosely: the English present perfect-are usually obtained by focusing the verb, as in:

(i) Vettem kenyeret. (cf. Kenyeret vettem. 'I bought bread.')

I-bought bread

'I have bought bread.'

24 This correlation makes a head-movement analysis very implausible for Hungarian: There would need to be some restriction stating that phrasal movement is required whenever the PM position is filled, and head-movement is required otherwise. (Note that nothing other than the PM is ever allowed to surface in the fronted phrase.)

${ }^{25}$ In fact, it is likely that in the case of verbal focus (such as (33b)), there is some silent adverbial element filling the PM position — as shown by the impossibility of having an overt PM in such sentences:

(i) *(Meg-látni) meg-láttam Párizst életemben.

(part-see-inf) part-saw paris-acc in-my-life

'(As for seeing it,) I have seen Paris in my life.' 
will not take the occurrence of infinitives without complements in Topic as an argument for head-movement, and continue to analyze these as instances of phrasal fronting where the phrase happens to contain only one overt element. ${ }^{26}$

A related fact observed in the literature is the difference between the fronting possibilities of copular be and verbal $b e^{27}$ (i.e., the be that is modified by an adverb). In Hebrew, for example, copular be cannot front by itself; this be can only be topicalized along with its complementan NP or AP. However, verbal be can appear alone in topic. At the same time, it's not clear how such a restriction should be formulated. Landau (2004) is led to conclude that (since auxiliaries also cannot front by themselves) "semantic richness" is the decisive factor here but the difference strikes me as more of a structural one: verbal be is inserted under $\mathrm{V}$, therefore we expect it to behave like other verbs. In particular, it (just like verbs in general) can be fronted alone as long as its complement is focused; observe an example from Hungarian:

(34) [Lenni] MeLlettem volt, de az agya láthatóan máshol járt. be-inf next-to-me was but the brain obviously elsewhere went

'He was actually next to me, but his mind was obviously somewhere else.'

If no such focusing takes place, verbal be takes its modifier along to its fronted position:

(35) [Otthon len-ni] otthon volt (de nem nyitott ajtót) home be-inf home was (but not opened door-acc)

'As for being at home, she was, but she wouldn't open the door.'

${ }^{26}$ As for the Hebrew examples cited above, it should be observed that there is also an interpretational difference between the two - namely, (32b) is similar in interpretation to (33c), involving focus on the direct object. This is noted in Landau's paper but he dismisses it as a possible motivation for the difference between $(32 \mathrm{a}-\mathrm{b})$ based on internal properties of Hebrew grammar (facts related to the position of negation and the form of pronouns occurring in this position). I will not comment on his examples here in particular, merely noting that a very similar problem in Hungarian can be resolved by taking into consideration the (visible) focus movement that precedes the fronting of the predicative phrase. Whether this line of analysis can be stretched to cover the Hebrew cases is unclear at best at this point.

${ }^{27}$ Landau does not use this terminology; I have added it for clarification. Note that by using these shorthand terms I do not wish to imply that the two types of be are separate lexical entries. On the contrary, I am assuming that the same (semantically impoverished) set of features can be inserted under different nodes to different structural effect. 
On the other hand, copular be is inserted (at least in Hungarian) higher than FP (probably under T), and therefore it is not present when FPfronting takes place: ${ }^{28}$

(36) Büszké-nek (*volt / *lenni) büszke volt. proud-dat was to-be proud was

'As for being proud, he was.'

Since all of these examples point in a single direction (namely, that the phrase affected by Hungarian predicate fronting always displays the same properties), I will disregard the possibility of head-movement to Topic, and concentrate on the identity of the fronted phrase. ${ }^{29}$

In the next short section I will attempt to characterize the projection I have been referring to as "FP" and provide an explanation for the special status of the modifier I have labeled "PM". In doing so, I hope to motivate a view of Hungarian syntax I have defended elsewhere and in different contexts: that the special status of the PM is due to the fact that it is merged lowest in the course of the derivation (in a predicative position)

${ }^{28}$ In Hebrew, the situation is obviously different, given that the copula can surface in the fronted constituent, while the fronting of the copula alone is ungrammatical, as seen below (Landau's example):

(i) Lihyot zamin, Gil lo tamid haya.

to-be available Gil not always was

'As for being available, Gil wasn't always.'

(ii) *Lihyot, Gil lo tamid haya zamin.

It seems to me that a reasonable explanation for this contrast cannot be semantic, since BE is semantically empty by definition. Nor is it easy to formulate a plausible rule restricting head-topicalization to verbal heads. Without attempting any serious analysis of the Hebrew facts, I would like to (tentatively) suggest that - since it does appear in the fronted phrase - the Hebrew copula is inserted lower than the Hungarian one, perhaps under F, and the non-verbal predicate head does not raise to it but remains inside its own phrase. (It appears after the copula in the fronted phrase, and is deleted from its base position, on a par with other complements.) In this case, the problem is re-formulated as follows: Why is it that the AP or NP cannot be focused or otherwise scrambled out of its base position (dominated by FP)? In a way, this is a similar situation to that of idioms: verbs taking idiomatic complements also cannot be fronted alone. Whether this would involve semantic incorporation or actual (covert) movement is an issue whose resolution is outside the scope of this paper.

${ }^{29}$ For further arguments against head-movement in predicate clefts, see Abels (2001). For an alternative view, doing away with the distinction between head and phrasal movement altogether, see Nunes (1999). 
- and ends up in (SpecFP) in the surface syntax of a neutral sentence. This line of analysis, in addition to making a lot of interesting predictions possible in other realms of syntax, also obviates the need for complicated definitions of the modifier of the relevant predicative phrase. ${ }^{30}$

It has long been known about the syntax of Hungarian that there is something special about the position left-adjacent to the verb in a neutral sentence (involving no focus or negation, which result in further verb movement, obscuring the lower positions). Primarily, the relationship between this (traditionally: $\mathrm{VM}=\mathrm{Spec}, \mathrm{AspP}$ or Spec,PredP) position and aspect has been investigated at length, the broad generalization being that the content of this position plays a crucial role in determining the aspectual and aktionsart properties of the sentence. In essence, the VM $(=\mathrm{PM})$ forms the main predicate in the sentence. This is precisely the factor that obscures its status - see footnote 9 for some comments.

In sentences containing more than one clause, it can happen that the $\mathrm{PM}$ of the lower clause raises to the matrix predicate, if the latter has no modifier of its own: ${ }^{31}$

(37) El akartam napolni a problémát.

part wanted-I postpone the problem-acc

'I wanted to postpone the problem.'

The particle el belongs to the lower verb (cf. Elnapoltam a problémát. 'I postponed the problem.'), but it raises to the matrix clause to form a complex between the two predicates (= "postpone-want" or similar, although the lower infinitive cannot surface in the PM position for independent reasons). Now we come to a case mentioned above, which bears directly on the identity of the phrase fronted:

30 This restriction sets the lower limit for the content of the fronted phrase but not the upper one: there may well be adjuncts (or even selected complements) inside the relevant phrase's base copy. These phrases do not have the special status of PM and therefore remain post-head. For simplicity's sake, I will assume in this paper that post-head material is deleted in Topic/Focus on identity with the lower copy, following well-established principles on the economy of pronunciation. In a phase-based approach it is very likely that FP will turn out to be a phase, in which case its domain has long been spelled out by the time topicalization occurs. Meanwhile its Spec and Head could be spelled out once more in a higher position.

${ }^{31}$ On the particulars of this, see É. Kiss (2002). 
(38) El napolni el akartam (*napolni) (de nem hagyták). ${ }^{32}$ part postpone-inf part wanted-I postpone-inf (but they didn't let me) 'I did want to postpone it but they didn't let me.'

It is clear from the example that, whatever the phrase fronted, it must be quite low in the structure - since on higher surface levels the combination el-napolni does not exist. This means that the particle and its predicate must have combined at some lower level, from there the particle has raised to become the PM of the matrix predicate, and the lower FP was subsequently fronted. Multiple pronunciation obtains because the PM is needed in the topicalized phrase for interpretation, while it is obligatory before the matrix predicate because of structural reasons, making both alternatives below ungrammatical:

(39) (a) *Napolni el akartam.

(b) *El-napolni akartam. (cf. *Akartam el-napolni.)

Therefore, the structure of (38) is as given in (40).

While it is quite intuitive, as well as widely documented in the literature on Hungarian syntax, that verbs are accompanied by a modifier bearing a certain designated status, the same is not nearly so obvious when it comes to non-verbal predicates. There are two factors obscuring the parallel between the two types of predication. I will discuss them briefly in turn.

32 This construction is very similar to one noted in Russian by Abels (2001).

(i) Čitat' (-to) on budet (*čitat').

read-inf to he will read-inf

'As for reading it, he will.'

Abels offers an explanation that captures the same idea outlined here, but in different words: doubling only happens when "the Base Line Sentence has only one exponent of both lexical content and tense information," which does not hold in complex verb forms. I would rephrase this as follows: "When the main verb is not the carrier of tense information (due to the presence of an auxiliary), it does not raise out of FP; therefore, when FP is fronted, it moves along with it, and is deleted on precise identity with the topicalized version." Anyway, this is what happens in Hungarian biclausal examples like (39) as well as analytic tenses exactly mirroring the Russian as in:

(ii) El-olvasni el fogom (*olvasni).

part-read-inf part will-I read-inf

'As for reading it, I will.' 
$(40)=(38)$

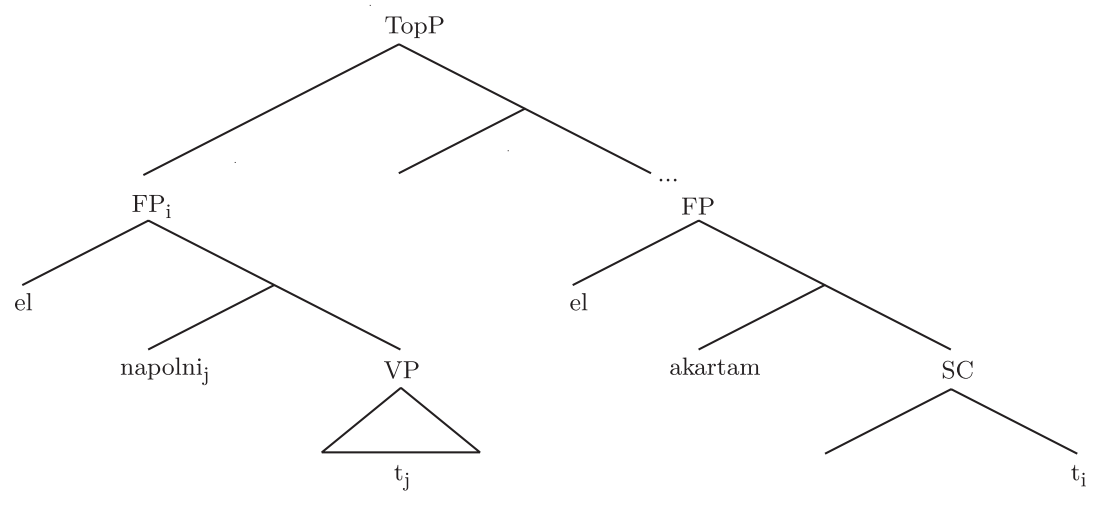

The first issue is related to the status of the nominal and adjectival predicates themselves, namely, that often they appear as modifiers to the copula. However, it is obvious that the level at which the complex of the predicate and the copula is formed is higher than the predicative phrase affected by topicalization or secondary predication, shown by the unavailability of the copula in these fronted phrases:

(41) (a) Gazdag-nak (*lenni) gazdag volt.

rich-dat be-inf rich was

'As for being rich, he was.'

(b) Gazdag-nak (*lenni) tűnt.

rich-dat be-inf appeared

'He appeared rich.'

So it is most natural to assume that at the relevant level the adjective (or noun) is the predicate, and it is not a complement or modifier to the copula, which is inserted higher into the structure.

A more complicated matter, however, is that non-verbal predicates can themselves have modifiers of various sorts, as mentioned above, but the order of these does not appear to be as fixed as the order of modifiers to the verb - at least at first glance:

(42) (a) [A fiai-ra büszke apa] végig-tapsolta a meccset. the sons-his-on proud father through-clapped the match-acc 'The father proud of his sons clapped all through the match.' 
(b) *[A fiai-ra büszke $]$ volt. the sons-his-on proud was 'He was proud of his sons.'

(c) Büszke volt a fiai-ra. proud was the sons-his-on 'He was proud of his sons.'

The issue is that while the adjective and its complement can evidently form a constituent in certain contexts (in an attributive position, as evidenced by (42a), they cannot form a complex predicate (shown by (42b)). This is loosely related to the observation that referential elements are generally not allowed as PM's - this position is restricted to predicative elements, which, by definition, cannot be referential. Thus, similarly to the situation with verbal predicates, certain modifiers of an adjective are most natural before the head, can appear along with the adjective in the position before the copula, and can front with the adjective to Topic:

(43) (a) [Közepesen magas] volt.

medium tall was

'He was medium height.'

(b) [Közepesen magas-nak] közepesen magas volt. medium tall-dat medium tall was

'As for being medium height, he was.'

Without going into too much detail of this question, which requires a lot of further investigation, I will suggest that similar modification structures exist in verbal and non-verbal predication, which is natural if the relevant structural level (our FP) is the same, regardless of whether it dominates a VP, AP or NP.

Further support for the status of modifiers such as in (43) comes from answering patterns. In Hungarian, it is possible to give an affirmative answer to a yes-no question by uttering the PM (i.e., the main assertion) from the question:

El-napoltad a problémát?

away-postponed-you the problem-acc 'Did you postpone the problem?'

A: El. 
This test can be used to distinguish between PM's and topics (which can also occur before the predicate, and although they cannot form a single intonational phrase with it, this is sometimes not so easy to tell). Now observe the distinct behavior of (42)- and (43)-type modifiers:

(45) Q: A fiaira büszke volt?

the sons-his-on proud was

'Was he proud of his sons?'

A: Büszke. /*A fiaira. / ${ }^{*}$ Volt.

The pattern above shows that the main predicate in this sentence is büszke, which means that a fiaira must be a topic. (It can also stay low in its base position, of course.) Now compare:

(46) Q: Közepesen magas volt?

medium tall was

'Was he medium height?'

A: Közepesen. / ${ }^{*}$ Magas. / *Volt.

The test indicates that the modifier közepesen constitutes the main assertion in the sentence, and must therefore be inside the predicative phrase. This, as mentioned above, correlates with the fact that it can (and must) front along with the adjective to TopP (see 43b).

Similar restrictions apply to nominal predicates, as shown below:

(47) (a) [Szigorú tanár-nak] szigorú tanár volt.

strict teacher-dat strict teacher was

'He was in fact a strict teacher.'

(b) Q: Szigorú tanár volt?

A: Szigorú. / *Tanár.

(c) *[Hivatalosan tanár-nak] hivatalosan tanár volt.

officially teacher-dat officially teacher was

Intended meaning: 'He was in fact an official teacher.'

(d) Q: Hivatalosan tanár volt?

A: *Hivatalosan. / Tanár.

Based on this drafty review of the relevant facts, I conclude that the analysis of the fronting of non-verbal predicates as FP fronting is wellfounded, not only by analogy with the situation with verbal predicates 
but also on independent grounds. This is desirable also because it provides a way to differentiate instances of FP-fronting on one hand and AP- or NP-fronting on the other, such as below:

(48) (a) Boldog' volt János de gazdag nem.

happy was John but rich not

'John HAS been happy (in his life) but not rich.'

(b) Boldog-nak' boldog volt János de mégis aggódtunk érte. happy-dat happy was John but still worried-we for-him 'Happy John was but we still worried about him.'

(c) Tanár' volt Judit de titkárnő nem. teacher was judit but secretary not

'Teacher Judit has been, but secretary she hasn't.'

(d) Tanár-nak' tanár volt Judit de csapnivaló. teacher-dat teacher was judit but really bad

'Judit was in fact a teacher but she was pretty bad at it.'

Under this analysis, the difference comes from the size of the chunk fronted: AP in (48a), NP in (48c), and FP in (48b) and (48d). This correlates clearly with the availability of modification in the two cases. As shown above, there are looser restrictions on modification inside AP (42a) (which may allow phrase-internal topicalization) than in SpecFP. Observe:

(49) (a) Volt már életében [AP (a fiaira) büszke (a fiaira)]... was already in-his-life the his-sons-on proud the his-sons-on 'He has been proud of his sons (in his life).'

(b) $[\operatorname{AP}(\mathrm{A}$ fiaira $)$ büszke (a fiaira) $]$ volt már életében... the his-sons-on proud the his-sons-on was already in-his-life 'As for being proud of his sons, he has been (in his life).'

(c) $\left[\left({ }^{*}\right.\right.$ A fiaira $)$ büszke $\left(*^{* a}\right.$ fiaira $\left.)\right]$ volt a fiaira. the his-sons-on proud the his-sons-on was the his-sons-on 'He was proud of his sons.'

(d) $\left[\mathrm{FP}\left({ }^{*} \mathrm{~A}\right.\right.$ fiaira $)$ büszké-nek $\left({ }^{* a}\right.$ fiaira $\left.)\right]$ büszke volt a fiaira. the his-sons-on proud-dat the his-sons-on proud was the his-sons-on 'As for being proud, he was of his sons.'

Therefore, I conclude that the status of the fronted predicate is (a) phrasal, and (b) distinct from the AP/NP containing the base copy of the predicate. I have labeled this phrase as FP. 


\section{Possible alternative analyses and comments on these}

Before concluding and summarizing what I have said so far, I want to briefly mention some possible alternative analyses of the Hungarian facts, and counterarguments to these. Some of these alternatives have been proposed in the literature, although not all - due to the fact that this construction in Hungarian has not received much attention in the past. Therefore, I have tried to anticipate theoretically possible alternatives to my analysis. All of the analyses below - in addition to having inherent problems - share the property that they lack any kind of connection between the fact that dative case in predicate fronting occurs on predicates and that dative case is a normal way to mark secondary predicates in Hungarian.

\subsection{Alternative Analysis A: \\ Dative case comes from the topic position (structural)}

This is clearly not the case, at least not in the strict sense-given that many kinds of elements can occur in that position without dative. One might argue, however, that predicates are the only elements that can be topicalized without already having received case - therefore the dative case associated with the position can only surface on them. This is again not true; observe an example similar to those already cited above:

(50) [Boldog] sokszor volt János (de gazdag nem).

happy many-times was John (but rich not)

'Happy John has been many times, but rich he has not been.'

When the AP, rather than the whole FP, is fronted - resulting in a contrast between two properties, rather than two predicates - no case occurs on the fronted predicate.

Also, the fronted predicative phrase can occur in focus rather than contrastive topic, as mentioned earlier as well, indicating that the dative case is not tied to a single structural position:

(51) [Csak boldog-nak] nem boldog (amúgy jól van).

only happy-dat not happy (otherwise well is)

'It's only that he is not happy, otherwise he is fine.' 
Based on these examples, I believe that the view that dative case in these constructions should be structurally tied to the surface position of the predicate is not tenable. Rather, under my analysis, the dative occurs as a result of a low position of the predicate also being the spell-out position, due to higher levels of structure.

\subsection{Alternative Analysis B:}

Dative case is inherent case, associated with the particular meaning 'as for the criterion of; from the aspect of...'

In Hungarian, there are some compelling arguments for this view, supported by cases such as:

(52) (a) Nekem / Péternek mindegy, mehetsz, ahova akarsz. I-dat Peter-dat all-the-same you-can-go where you-want 'It's all the same to me/to Peter, you can go where you want.'

(b) Neked / ? Péter-nek ez kék?! ${ }^{33}$

you-dat Peter-dat this blue

'This is blue in your/Peter's opinion?!'

These datives are always optional, and carry a very specific meaning: 'in the opinion of'. In this regard, they show a very close connection to the so-called 'ethical dative', as in:

(53) Már megint összetöri magát nekem / *Péternek.

yet again breaks self-acc I-dat Peter-dat

'He will get hurt "on me" / "on Peter" again.'

At the same time (in contrast with the predicate fronting datives), the types of dative in (52)-(53) are highly constrained. The ethical dative is always pronominal and clause-bound, while the opinion-datives in $(52 \mathrm{a}-$ b) are also only possible with the types of predicates that allow the expression of an 'opinion' reading - compare:

(54) (a) *Nekem / *Péter-nek háromemeletes a ház.

I-dat Peter-dat three-storey-tall the house

Intended reading: 'In my/Peter's opinion, the house is three stories tall.'

33 Thanks to Edith Kádár (p.c.) for calling my attention to this example. 
(b) Háromemeletes-nek háromemeletes, de még így is a legalacsonyabb three-storey-tall-dat three-storey-tall but still so also the smallest az utcában. the street-in 'It's true that it is three storeys tall but it's still the smallest in the street.'

I think it is clear from these examples that these two meanings of datives are not related. Nevertheless, the structural position of the ethical and opinion datives may also be syntactically fixed - this is something for further research.

\subsection{Alternative Analysis C: \\ Dative case is a default case in Hungarian (Burányi 2003)}

Besides the fact that "default case" is a strange theoretical concept to begin with, there is no reason to assume that dative should be a default. Some of the cases cited elsewhere in the literature to support the idea of default dative-e.g., sentences like It's me in English - also involve predication; in fact, the 'dative' pronoun is a predicate. Nevertheless, to the extent that such a thing as 'default case' does exist, this does not explain its occurrence in the predicate fronting examples discussed here. Predicates do not need case, and so they don't need default case either.

Note that on the analysis advanced in this paper the same question can be turned around: if predicates do not need case, yet they bear dative case in a lot of examples, why and how do non-predicates receive dative? In other words, is dative case 'structural' in the sense that nominative and accusative are? The most desirable answer and an answer that I hope to investigate in upcoming work is naturally that dative always occurs on predicates. ${ }^{34}$

${ }^{34}$ Aside from theoretical objections, some of the data cited by Burányi in his paper is also questionable. Most importantly, he claims that verb modifiers that are not particles cannot be fronted along with the verb, making the example below ungrammatical:

(i) Kenyer-et ven-ni kenyer-et vett.

bread-acc buy-inf bread-acc bought

'As for bread-buying, that's what he did.'

Since according to my own judgment, as well as the opinion of about a dozen informants, the sentence above is well-formed, I can only assume that Burányi was working on a different dialect of Hungarian. Therefore, I believe it is pointless to 


\section{Summary and conclusions}

In this paper I have presented data and arguments to support a uniform structure of FP dominating the lexical projection of the predicate-VP, NP or AP. I have argued that the internal properties of this phrase hold the key to various questions - among them the type of modification allowed in positions where FP is spelled out. I have shown that the internal modification patterns of $\mathrm{FP}$ and $\mathrm{NP} / \mathrm{AP}$ are visibly different in Hungarian. I have also claimed that the dative and infinitive forms showing up in fronted predicates are a reflex of the $\mathrm{F}$ head; more precisely, the spell-out of $\mathrm{V}$ in $\mathrm{F}$ is the infinitive, and of $\mathrm{N}$ or $\mathrm{A}$ in $\mathrm{F}$ is the dative. As a side-issue I have suggested that the semantically empty features that constitute be can be inserted under the verbal node in Hungarian, yielding an element that behaves like a verb in the relevant respects, or these features can surface under T, which is the traditional "copula". This distinction explains the fact that the "copula" does not occur in the topicalized predicative phrase - since it is inserted higher than FP, its appearance would be unexpected.

One of the interesting characteristics of the internal structure of FP in Hungarian is the piling up of lower predicative elements in the specifier of the matrix predicate. In an "upward" derivation we witness each lower predicate to pick up and move into FP, which in turn moves up to become the Predicate Modifier of the matrix predicate and so on. According to this observation, we can expect various elements to start out from a predicative position, which is strongly in line with a wide variety of current research. ${ }^{35}$ More strongly, a strict correlation between the surface position (Spec,FP) and the base position (inside a lexical projection dominated by FP) can be seen. This is intuitively appealing, since the idea that every sentence should only have one "main" predicate (however complex) is not a strange one. Hungarian may be a language where the various layers of predication unite to a large extent in overt syntax. Naturally, a question that I have left open - the exact nature of FP (= AspP, PredP, FocP or something entirely different) - will play a crucial role in formalizing this intuition.

go into the details of his analysis - given that one of the cornerstones of my paper has been that verb-modifiers can and always must front with their predicate.

35 See for example den Dikken (forthcoming); Larson (2004); on Hungarian: É. Kiss (2002) for a predicative analysis of verb-modifiers, and so on. 
A related issue is the status of datives in this picture. I have suggested that this research is aimed at supporting a more general line of thought, namely, that datives are predicative elements. This is a very appealing prospect, ${ }^{36}$ and I believe that the properties of datives in Hungarian add significantly to the plausibility of this programmatic claim. In other terms, the idea that "case" should be correlated with features already necessary in syntax (i.e., the connection between nominative case and tense, accusative case and aspect) has been around for a long time. As for dative case, it has received slightly less attention, although the relationship between dative and the complexity of events (here: the complexity of predication) is discussed at length for example in Svenonius (2002). In my opinion, the implications of research along these lines are extremely promising and far-reaching.

In upcoming research, I hope to untangle many of the above mentioned matters.

\section{References}

Abels, Klaus 2001. The predicate cleft construction in Russian. In: Steven Franks Tracy King - Michael Yardoff (eds): Formal approaches to Slavic linguistics 9: The Bloomington Meeting 2000, 1-18. Michigan Slavic Publications, Ann Arbor.

Bowers, John 2001. Predication. In: Mark Baltin-Chris Collins (eds): The handbook of contemporary syntactic theory, 299-333. Blackwell, Malden MA \& Oxford.

Burányi, Péter 2003. Kettős predikálás: ismételt predikátumok kontrasztív topik pozícióban [Double predication: Repeated predicates in contrastive topic position]. In: Zsuzsanna Gécseg (ed.): LINGDOK 2. Nyelvészdoktoranduszok dolgozatai [Papers by doctorate students of lingustics], 48-70. Szegedi Tudományegyetem, Nyelvtudományi Doktori Iskola, Szeged.

Cable, Seth 2004. Predicate clefts and base-generation: Evidence from Yiddish and Brazilian Portuguese. Paper presented at the ECO5 Syntax Workshop, University of Maryland.

Davis, Lori J.-Ellen F. Prince 1986. Yiddish verb-topicalization and the notion "Lexical Integrity". In: Anne M. Farley-Peter T. Farley - Karl-Erik McCullough (eds): Papers from the 22nd Regional Meeting, 90-7. Chicago Linguistic Society, Chicago.

Dikken, Marcel den 1999. On the structural representation of possession and agreement: The case of (anti-)agreement in Hungarian possessed nominal phrases. In: István Kenesei (ed.): Crossing boundaries: Advances in the theory of Central and Eastern European languages, 137-78. John Benjamins, Amsterdam.

${ }^{36}$ I refer the reader to den Dikken's extensive work on possession and related matters. 
Dikken, Marcel den forthcoming. Relators and linkers: The syntax of predication, predicate inversion, and the copula. MIT Press, Cambridge MA.

É. Kiss, Katalin 2001. A fönévi igenév személyragozásának kérdéseiről [On inflected infinitives]. In: Marianne Bakró-Nagy-Zoltán Bánréti-Katalin É. Kiss (eds): Újabb talulmányok a strukturális magyar nyelvtan és nyelvtörténet köréből [New studies on the structural grammar of Hungarian and the history of language], 249-73. Osiris Könyvkiadó, Budapest.

É. Kiss, Katalin 2002. The syntax of Hungarian. Cambridge University Press, Cambridge.

Komlósy, András 1992. Régensek és vonzatok [Valence and government]. In: Ferenc Kiefer (ed.): Strukturális magyar nyelvtan 1. Mondattan [A structural grammar of Hungarian, Vol. 1: Syntax], 299-527. Akadémiai Kiadó, Budapest.

Landau, Idan 2004. Constraints on partial VP fronting. Manuscript. Ben Gurion University.

Landau, Idan 2006. Chain resolution in Hebrew V(P)-fronting. In: Syntax 9:32-66.

Larson, Richard 2004. Sentence-final adverbs and scope. In: Matthew Wolf-Keir Moulton (eds): Proceedings of NELS 34, 23-43. GLSA, Amherst.

McCoy, Svetlana 2002. Semantic and discourse properties of colloquial Russian construction of the form "X-to X, a...". In: Glossos 3. (http://seelrc-web.aas.duke.edu/glossos/)

Nunes, Jairo 1999. Linearization of chains and phonetic realization of chain links. In: Samuel David Epstein - Norbert Hornstein (eds): Working minimalism, 217-49. MIT Press, Cambridge MA.

Pesetsky, David 1995. Zero syntax: Experiencers and cascades. MIT Press, Cambridge MA.

Svenonius, Peter 2002. Case is uninterpretable aspect. In: Angeliek van Hout - Henriette de Swart-Henk Verkuyl (eds): Proceedings of the Perspectives on Aspect Conference. University of Utrecht, Utrecht.

(http://www-uilots.let.uu.nl/conferences)

Tóth, Ildikó 2002. Can the Hungarian infinitive be possessed? In: István Kenesei-Péter Siptár (eds): Approaches to Hungarian 8 (Papers from the Budapest conference), 133-60. Akadémiai Kiadó, Budapest.

Vicente, Luis 2005. Towards a unified theory of movement: An argument from Spanish predicate clefts. In: Leiden Papers in Linguistics $2.3: 43-67$. 